Session 2651

\title{
SYSTEMS APPROACH TO INCORPORATE DESIGN INTO ENVIRONMENTALLY CONSCIOUS DESIGN AND MANUFACTURING COURSE
}

\author{
Yaw A. Owusu, Tarsha Dargan, Kimberly M. Richardson, James Thagard \\ FAMU-FSU College of Engineering \\ Florida A \& M University/Florida State University \\ Tallahassee, Florida
}

\begin{abstract}
Understanding or predicting the consequences of a specific action or circumstance is especially difficult in the case of environmental issues, which exhibit several forms of uncertainty. Many natural systems such as the atmosphere or oceans, however, appear to be inherently chaotic, and their evolution through time is uncertain. The inevitability of uncertainty in dealing with environmental issues is compounded in terms of industrial ecology that must integrate a changing technology with two sets of complex systems, namely the environmental and the economic. In most cases, the uncertainty is defined and managed through evaluating and quantifying risk. In this paper, a method of systems approach has been used incorporate design into environmentally conscious design and manufacturing (ECDM) course. A systems approach design model has been developed for environmental auditing for manufactured products starting from raw material extraction to the final disposal of the manufactured product. The design criteria are the methods by which the environmental friendliness or customer requirements are met in the design arena. In addition to the basic design requirements for environmentally conscious design and manufacturing, sample case studies have been provided in order to elucidate the concepts covered in ECDM course. The design content adopted in this paper, emphasizes a proactive approach to environmental management that requires that the concept of environmentally conscious manufacturing (ECM) be integrated throughout the company's management structure and the production system.
\end{abstract}

\subsection{Introduction}

Historically, environmental management at a manufacturing facility was considered as an afterthought. Waste and emission treatment technology was incorporated as an end-of-pipe design, rarely as an integral part of the manufacturing operation. The end-of-pipe reaction to environmental control only encouraged more environmental control as each new treatment method failed to provide a permanent solution to harmful wastes and emissions.

For the design to be effective, several underlying trends deserve attention. The first trend is the diminution of regional and global abilities to deal with anthropogenic emissions. For example, 
carbon dioxide production associated with human economic activity has grown dramatically in the last few years, largely because of extremely rapid growth in energy consumption ${ }^{1,2}$. This pattern is in keeping with the evolution of the human economy to a more complex state, increasing growth in materials use and consumption, and an increased use of capital. The second trend is high world population growth and the associated energy consumption to satisfy human activities and needs.

\subsection{Design Component of Industrial Ecology in ECDM Course}

No firm or organization exists in a vacuum. Every industrial activity is linked to thousands of other transactions and activities and to their environmental impacts. A large firm manufacturing high-technology/low-material products will have many suppliers located all around the world and changing on a daily basis. It may manufacture and offer for sale hundreds of thousands of individual products to myriad of customers, each with her or his own needs and cultural characteristics. Each customer, in turn, may treat the product very differently, a consideration when use and maintenance of the product may be a source of potential environmental impact (e.g., used oil from automobiles). When finally disposed of, the product may end up in almost any country, in a high-technology landfill, an incinerator, beside a road, or in a river that supplies drinking water to local populations.

In such a complex circumstance, how has industry approached its relationships with the outside world? Satisfying the needs of its customers has always been well done. Industry has, however, been less adept at identifying some of the long-term consequences of the ways in which it goes about satisfying needs. James Wei of Princeton University ${ }^{3}$ has collected examples of a few of these interactions; we adapt and display that information here as Table 1. The table indicates the difficulties created for society in a world in which industrial operations are perceived as essentially unrelated to the wider world. It is important to note that the relationships in Table 1 were not the result of disdain for the external world by industry. Several of the solutions were, in fact, great improvements over the practices they replaced, and their eventual consequences could not have been forecast with any precision. What was missing, however, was any attempt to relate the techniques for satisfying customer needs to any possible environmental consequences.

Table 1. Relating Current Environmental Problems to Industrial Responses to Yesterday's Need ${ }^{3}$.

\begin{tabular}{|c|c|c|}
\hline Yesterday's Need & Yesterday's Solution & Today's Problem \\
\hline $\begin{array}{l}\text { Nontoxic, non- } \\
\text { flammable refrigerants }\end{array}$ & $\begin{array}{l}\text { Chlorofluoro- } \\
\text { carbons }\end{array}$ & Ozone hole \\
\hline $\begin{array}{l}\text { Automobile engine } \\
\text { knock }\end{array}$ & Tetraethyl lead & $\begin{array}{l}\text { Lead in air } \\
\text { and soil }\end{array}$ \\
\hline Locusts, malaria & DDT & $\begin{array}{l}\text { Adverse effects } \\
\text { on birds, mammals }\end{array}$ \\
\hline $\begin{array}{l}\text { Fertilizer to aid } \\
\text { food production }\end{array}$ & $\begin{array}{l}\text { Nitrogen and phosphorus } \\
\text { fertilizer eutrophication }\end{array}$ & Lake and estuary \\
\hline
\end{tabular}


Although making such attempts does not ensure that no deleterious impacts will result from industrial activity, these actions have the potential to avoid the most egregious of the impacts and to contribute toward incremental changes in the impacts that are now occurring or can be well forecast. How are such attempts best made? The approach to industry-environment interactions that is described in this paper to aid in evaluating and minimizing impacts is called "industrial ecology" (IE). Industrial ecology as applied in manufacturing involves the design of industrial processes and products from the dual perspectives of product competitiveness and environmental interactions.

Industrial ecology is the means by which humanity can deliberately and rationally approach and maintains a desirable environmental impact, given continued economic, cultural, and technological evolution. The concept requires that an industrial system be viewed not in isolation from its surrounding systems, but in concert with them. It is a system approach view in which one seeks to optimize the total materials cycle from virgin material, to finished material, to component, to product, to obsolete product, and to ultimate disposal. Factors to be optimized include resources, energy, and capital.

One of the most important concepts of industrial ecology is that, like the biological system, it rejects the concept of waste. Dictionaries define waste as useless or worthless material. In nature, however, nothing is eternally discarded; in various ways, all materials are reused, generally with great efficiency. Nature has adopted this approach because acquiring these materials from their reservoirs is costly in terms of energy, resources and environmental impact, and thus something to be avoided whenever possible. In our industrial world, discarding materials extracted from the earth at a great cost is also generally unwise. Hence, materials and products that are obsolete should be termed residues rather than wastes, and it should be recognized that wastes are merely residues that our economy has not yet learned to transform into useful products efficiently.

\subsection{The Master Equation for ECDM Application}

Human population growth is, of course, a major factor fueling explosive industrial growth and expanded use and consumption of materials. Since 1970, human population has grown 8-fold: it is now approximately 6 billion and is anticipated to peak at between 10 and 15 billion late in the twenty-first century. The stresses on many aspects of the earth system are strongly influenced by the needs of the population that must be provided for and by the standard of living that population desires. One of the famous expressions of these driving forces is provided by the socalled "master equation":

Environmental impact $=($ population $) \times((G D P) /($ person $)) \times($ environmental impact $) /$

where GDP is a country's gross domestic product, a measure of industrial and economic activity. Let us examine the three terms in this equation and their probable change with time. 
Of the trends for the three terms of the master equation, the one that perhaps has the greatest degree of support for its continuation is the second, the gradual improvement of the human standard of living, defined in the broadest of terms. The first term, population growth, is not primarily a technological issue but a social issue. Although different countries approach the issue differently, the upward trend is clearly strong. The third term, the amount of environmental impact per unit of output, is primarily a technological term, though societal and economic issue provides strong constraints to changing it rapidly and dramatically. It is this third term in the master equation that offers the greatest hope for a transition to sustainable development and it is modifying this term that is the central tenet of industrial ecology; and therefore, it must be the focal point for the design component of ECDM course.

\subsection{Design Model for Risk Assessment for ECDM Courses}

The inevitability of uncertainty in dealing with environmental issues is compounded for the industrial ecological student, who must integrate a changing technology with two sets of complex systems, the environmental and the economic systems. In most cases, the uncertainty is defined and managed through evaluating and quantifying risk factors for the environment. Perhaps, the product life cycles analysis is the best systems approach to solving such a complex design problem.

To organize a course in design for environmentally conscious design and manufacturing (ECDM) implies the infusion of environmental considerations into traditional design and manufacturing methodologies. It is necessary to modify the conventional course material and method of delivery by taking into consideration the environmental impact of a manufactured products and processes used to make those products. The product life cycle of typical products is shown in Figure 1. The emphasis of systems approach to design for a course in ECDM is to consider the concept of "from cradle to grave" for each product or system of manufacture including the efficient extraction of product from raw materials, the minimizing/eliminating waste generation at the source, or possibly the use of waste to create other products. This initiative offers excellent possibility of reducing costs to industry and society, maximizing resource use, and establishing new environmentally efficient industries. The desired end goal of ECDM is the design of products and/or processes that have minimal environmental consequences.

ECDM involves the creative application and modification of fundamental theories, models, and procedures from engineering and science and applying them to the environmental and manufacturing domain. The ECDM systems approach involves setting up criteria, weights (performance metrics) and hierarchies that exemplify the differing objectives, as well as, the development of design tools that can simultaneously handle multiple and often conflicting objectives.

The design content for the ECDM course by the authors consists of five modular components for environmental index measurement, namely (as shown in Figure 2):

- Material Extraction 
- Material Processing

- $\quad$ Manufacturing / Assembly

- $\quad$ Product Use

- Waste Management.

Modules are related and interactive:

- Database oriented (using Microsoft Access or any other data base structure).

- $\quad$ Automated generation of environmental indices based on database information and user defined data.

- $\quad$ Possible for use during the design and process planning phase.

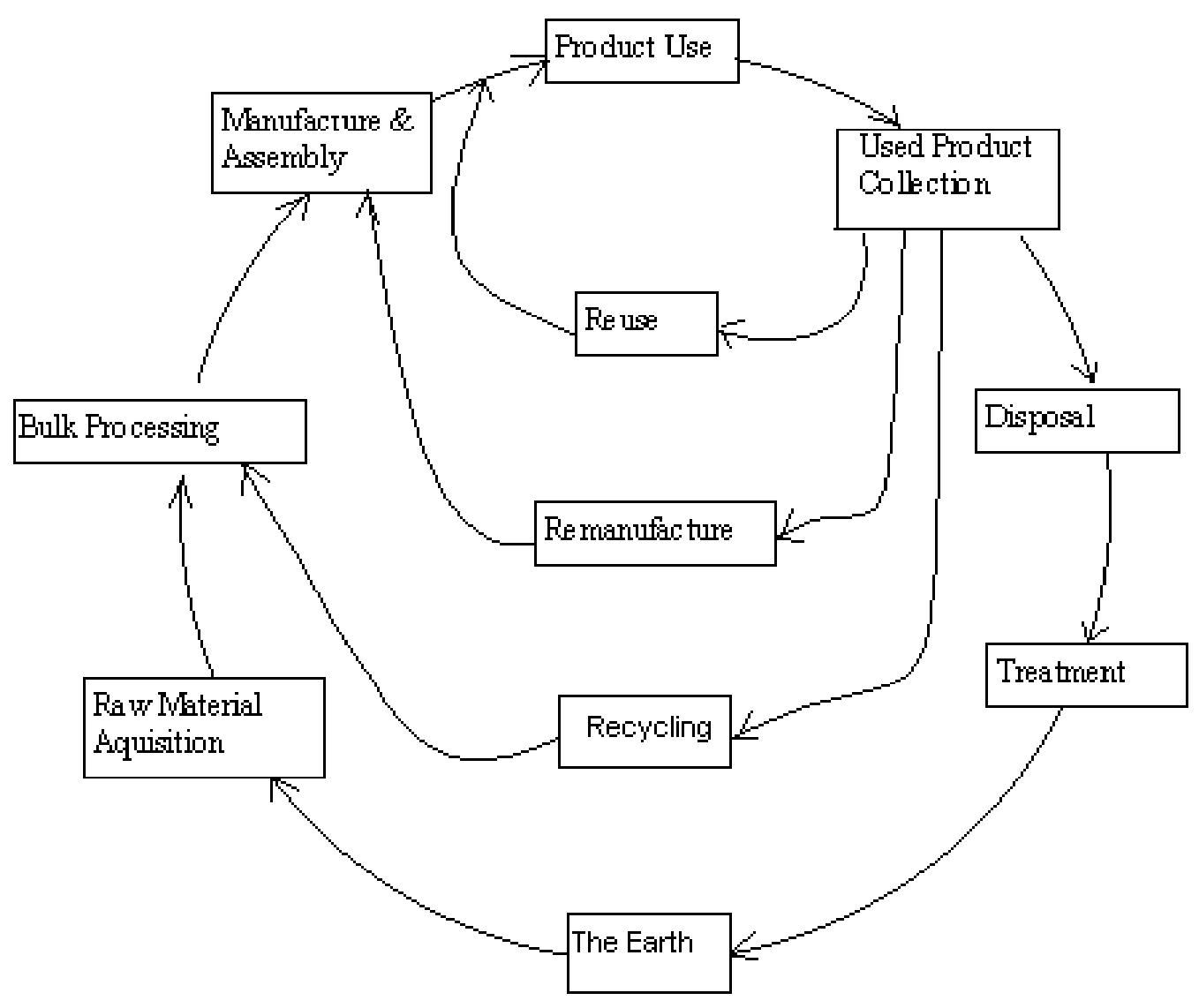

Figure 1. System Approach to Product Life Cycle Analysis for a Course in ECDM.

The data structure must permit information generated by modules to be incorporated into database and passed along to each model using aggregate rating based on results of different modules. The different rating systems used include: materials life cycle, process life cycle, and 
complete product / process life cycle. Each module is to be independent and self contained; stand-alone modules using a common database as a source of reference.

\subsection{Summary of How the Program Works}

At each stage of the life cycle design process, specific questions for that stage will be asked of the user for specific information regarding that stage. The program uses the information given, as well as information stored within the database (if necessary) to tabulate an environmental rating for that stage. The program then returns the rating to the database for storage and later usage. Finally, the main program tabulates the total aggregate environmental rating based on the number of operations and processes at each stage of the product life cycle.

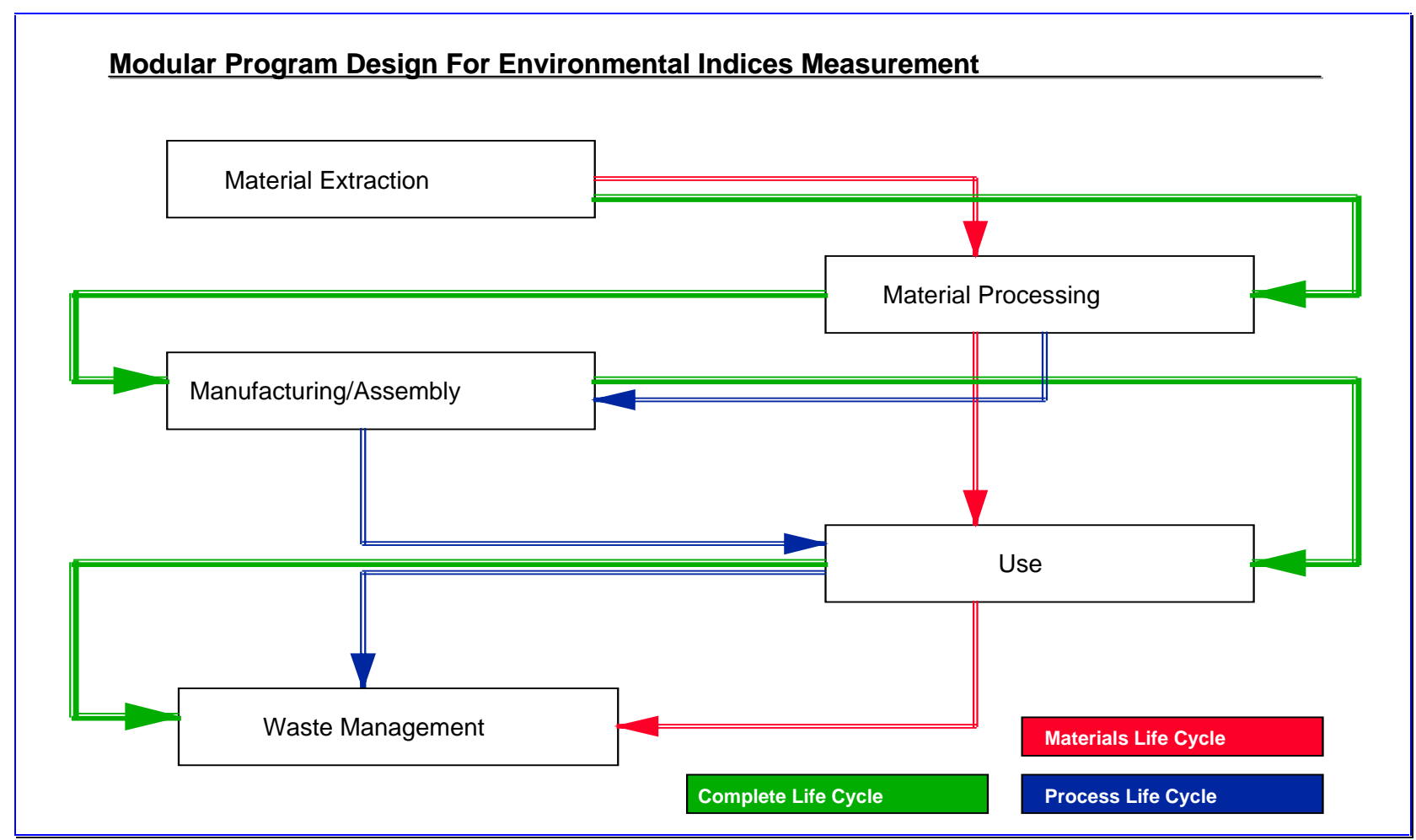

Figure 2: $\quad$ Modular Design Program for Environmental Indices Measurement.

\subsection{Details for Program Design Modules}

\section{Material Extraction Module}

The first module for use in the design or rating of a process is extraction of materials from an area. Sample questions for tabulation of rating in material extraction module:

- What is the rate of material extraction?

- What is the reserve of materials where the extraction is taking place?

- How much material is lost during extraction? 
- $\quad$ How much energy is consumed during the extraction process?

- What percent of the surrounding area is affected by the extraction of materials?

The characteristics for tabulation of rating(s):

- looks at efficiency, energy usage, time until complete degradation of reserve, percent effects on the surrounding environment, recyclable and unrecyclabel waste generated per process, etc.

- The rating given will be:

- $\quad$ per process

- $\quad$ aggregate rating of the total operations at that stage

- $\quad$ provide flags for abnormally high ratings.

\section{Material Processing Module}

The material processing module is used during the processing stage of the material(s); and the sample questions asked include:

- What is the efficiency of the process?

- How much energy is used during the process?

- $\quad$ Types of energy systems being used-renewable or non-renewable, etc.

- How much emmision material is given off during the process?

- What and how many extra (catalyst) materials are used during the process, and What percent of these materials environmentally impact ecological system?

- What percent of environmental risk is in the process itself?

- What percentage of human and environmental risk is involved in the process?

Characteristic tabulation of rating(s):

- Looks at efficiency, energy usage, material usage, percent risks to and emission effects on the surrounding environment, recyclable and unrecyclable waste generated per process, etc.

- $\quad$ The rating given will be:

- $\quad$ per process

- $\quad$ aggregate rating of the total operations at that stage

- $\quad$ provide flags for abnormally high ratings.

\section{Manufacturing / Assembly Module}

This module involves rating in manufacturing processes such as machining, casting, forging, welding, etc., and assembly operations. Sample questions for tabulation of rating include:

- How much energy is consumed during the process?

- Types of energy systems being used-renewable or non-renewable, etc.

- What materials are used during the process?

- How efficient is the process?

- What percentage of the processing materials can be reused?

- What percentage of the non-reusable material constitutes an environmental risk?

- What percentage of excess materials can be considered "industrial emissions"? 
This module involves ratings of the actual operation and use of a product. Sample questions for tabulation of rating include:

- How much energy is consumed by the product?

- How efficient is the product?

- What percentage of the product can be reused?

- What percentage of use of the product constitutes an environmental risk?

- How much waste is generated by the product?

\section{Waste Management Module}

This module is used for rating the waste characteristics of a product; and sample questions asked include the following:

- What percentage of the product can be recycled?

- What percentage of the product can be reasonably disassembled / shredded, etc.

- What percentage of the product is biodegradable?

- What percentage of non-reusable / non-recyclabe parts of the product constitutes an environmental risk?

- How much energy will be required to dispose of the product?

\section{Important Characteristics of the Main Program}

The major characteristic for the main design program:

- $\quad$ Gives total rating of processes and product together.

- $\quad$ Gives specific views of product and processes such as materials view and processes view.

- $\quad$ Program and modules operate with certain goals in mind:

- $\quad$ minimization of waste and environmental risk

- $\quad$ minimization of energy usage and consumption

- $\quad$ highlight (flag) opportunities for improvement.

- $\quad$ stores given information, associated with specific product or process.

- $\quad$ Contain specific materials information and general process information.

- Tailorable to specific industry.

- $\quad$ Still under research and consideration.

\subsection{Useful Equations and Data Structure for ECDM Design Model}

It is instructive to use materials flow as depicted in Figure 3 to define and compute measures of efficiency so that societal progress in industrial ecology can be measured or assessed. This is a systems approach methodology to be incorporated ECDM courses: Extracting Efficiency, Manufacturing Efficiency, Recovery Efficiency, Recycling Efficiency, and overall System Efficiency.

The equations are based on the mass flows documented in shown in Figure 3, where $\mathrm{V}=$ virgin material, $\mathrm{M}=$ processed materials, $\mathrm{P}=$ product, $\mathrm{S}=$ salvaged material, $\mathrm{I}=$ impure material, and $\mathrm{W}=$ waste. 
Extracting Efficiency $(\tau)$ :

$$
\tau=\mathrm{M} /(\mathrm{V}+\mathrm{l})
$$

If no virgin material is used and no residue is produced, then $\tau=1$. This is a function of good extraction technology, high-quality residue streams, and negotiated manufacturer's specification and recommendations.

Manufacturing Efficiency $(\mu)$ (a function of process and product deign, and their implementation):

$$
\mu=\mathrm{P} /\left(\mathrm{P}+\mathrm{W}_{\mathrm{m}}\right)
$$

where $\mathrm{W}_{\mathrm{m}}$ is the manufacturing process-residue stream mass. If no manufacturing residue is generated, then $\mu=1$.

Materials Extractor
Or Grower

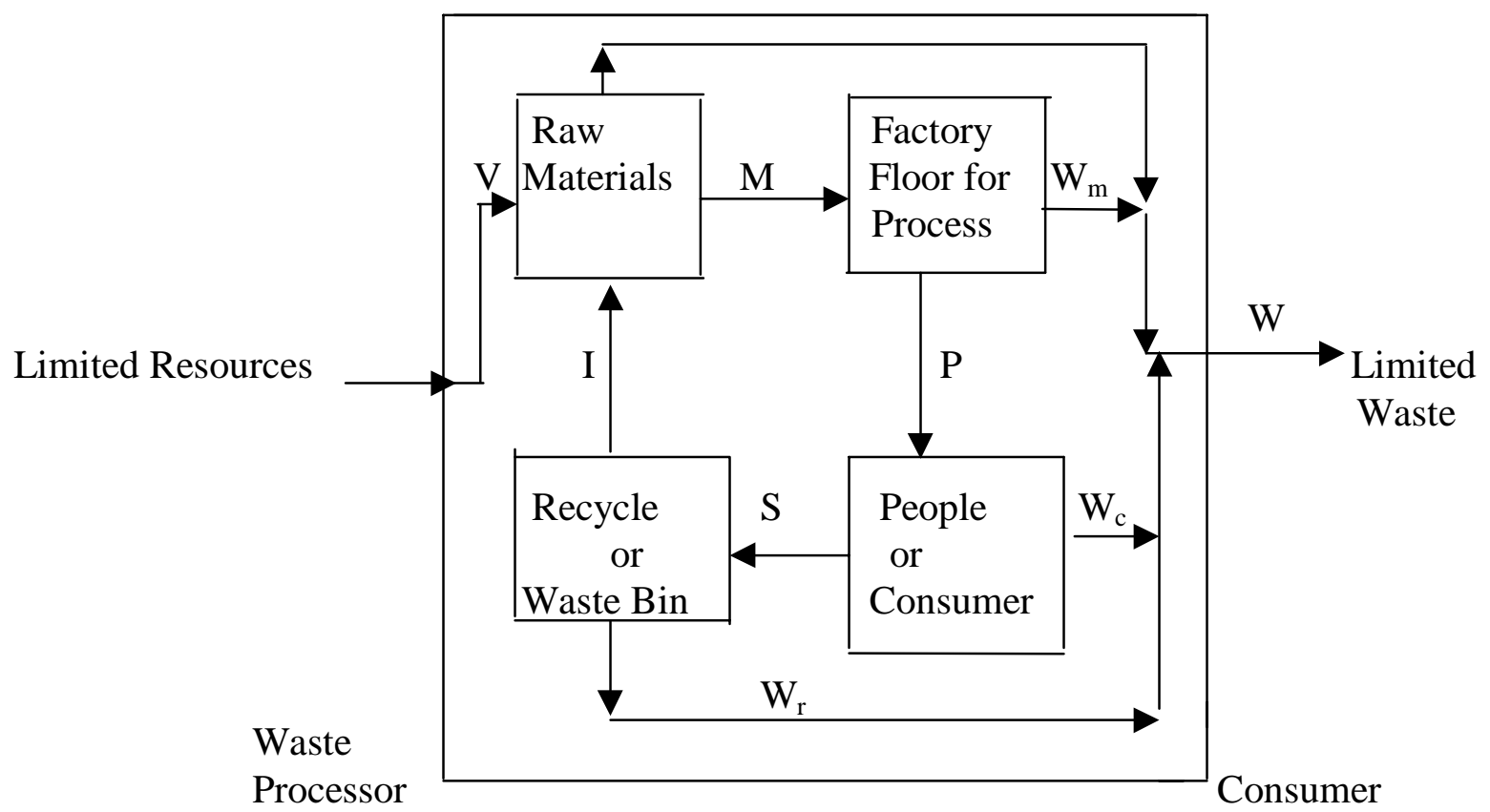

Figure 3. Schematic View of Mass Flow in the Ecosystem Using systems Approach.

Recovery Efficiency ( $\rho$ ) (a function of product design, government policies, recycled materials market):

$$
\rho=S /\left(S+W_{c}\right)
$$

where $\mathrm{W}_{\mathrm{c}}$ is unrecycled-residue stream mass. If all material is recycled, then $\rho=1$. 
Recycling Efficiency $(\lambda)$ (a function for "design for assembly" and government and customer regulations and policies):

$$
\lambda=\mathrm{I} /\left(\mathrm{I}+\mathrm{w}_{\mathrm{r}}\right)
$$

where $\mathrm{W}_{\mathrm{r}}$ is recycling-residue generated stream mass. If no recycling residue is generated, then $\lambda=1$.

An overall reuse factor $(\Psi)$ can be defined as:

$$
\Psi=\mathrm{I} / \mathrm{M}
$$

and overall System Efficiency $(\sigma)$ is given by:

$$
\sigma=\tau \times \mu \times \rho \times \lambda
$$

In a perfectly ecological balanced system in which all materials are provided by recycling, the overall system efficiency will be $1(\sigma=1)$.

\subsection{Systems Approach for Establishing a Proactive Corporate Management Structure}

The proactive approach to environmental management requires that the concept of environmentally conscious design and manufacturing (ECDM) be integrated throughout the company's management structure. Integrating ECDM into the company's operations involves a two-step process. The first step is to create a supportive management structure within the company for proactive environmental management. The second step is to use that supportive atmosphere created to establish and communicate an environmentally conscious business plan.

The use of "cross-functional resources" is necessary to be effective in implementing pollution reduction, waste reduction, or design and manufacturing for the environment. The use of crossfunctional resources assumes that no individual has all the knowledge and a resource available to implement changes that cut across all levels of a company. Therefore, in the design component of the ECDM course, students must be aware and 'role-play' that companies use people with talents in specific areas to most efficiently achieve the desired results. A crossfunctional environmental management team is a dynamic group. Not all individuals' talents are needed throughout a project. Therefore, people come into the group and leave as necessary.

\subsection{Management Resources}

New concepts in pollution prevention, design for the environment (DFE), total quality environment management (TQEM), and life cycle analysis (LCA) invoke a much larger scope, a scope that cannot be addressed by a few individuals at the facility level. These new concepts require that companies evaluate the environmental friendliness of the product. Product "environ-soul searching" can consider the raw materials used, the manufacturing process, the energy requirements, packaging issues, recyclability, and the environmental value of the product itself. These issues cannot be addressed at the facility level. However, they require input from the marketing, research and development, design engineering, process engineering, and manufacturing engineering. The resources and talents necessary to address these issues are 
typically found not at the facility level but at the divisional or corporate levels of a company. Other personnel involved in this effort must also include corporate environmental staff, purchasing, accounting, and finance.

\subsection{Incorporation of an environmental Business Plan into ECDM Course}

Once a proactive corporate structure is in place, business planning based on environmentally conscious design and manufacturing can begin. Most successful companies rely on a long-term business plan to ensure their future growth and success. Developing a business plan requires that a company identify potential markets, the competition's vulnerability, and the company's strengths. Therefore, environmentally business plan must be taught and discussed as a part of the core material in ECDM course.

In preparing a plan, students must develop and investigate the options for preventing the generation of wastes or release of pollutants. The plan must address a facility's operations during a specified time period, and it must be updated periodically. Common elements of a pollution prevention business plan include the following general outline:

- Environmental policy statement.

- Description of current waste- or emission-generating process.

- Description of past and current practices used to eliminate or reduce generation of waste and toxic pollutants.

- Identification of pollution prevention options that are both economical and practical.

- Waste and pollution prevention objectives with numerical goals.

- Rationale used to develop each goal.

- Options that are not economically or technically feasible must be spelt out and eliminated.

\subsection{Measurement or Evaluation of Progress for Environmental Business Plan}

Students and companies who develop environmentally conscious business plans must have a methodology of evaluating the effectiveness of their plans and work towards future improvement. Perhaps, the best procedure or method of determining or measuring the progress of environmentally conscious design and manufacturing plan is the quantitative analysis of product life cycle based on "environmental impact indices" (EII). EII considers the raw materials used, the manufacturing process adopted, the energy requirements, the waste produced, packaging issues, recyclability, and the environmental correctness of the product itself. In this paper a case study cited here is based on the generation of electricity from either coal or solar energy. This is a typical design work incorporated into ECDM course by the authors.

\subsection{Case Study: Evaluation of Environmental Impact on Electricity Generation from Coal and Solar (as Alternative Energy Source)}

This is an actual design work done by students in environmentally conscious design and manufacturing (ECDM) course offered at FAMU-FSU College of Engineering. This case study helps to elucidate and evaluate the environmental impact on generating electricity from coal and 
solar energy, as alternate energy sources. Computer software was developed for this analysis using Microsoft Access database structure.

\section{Program Description}

A software package has been designed that enables users to determine the environmental impact of producing various products. The software consists of five independent modules that evaluate products from a total life cycle approach.

\section{Module 1}

Material Extraction is the beginning of the product life cycle. It determines the environmental impact of removing the raw materials from their natural state. The module includes evaluating the depletion of the material reserve, ending with the disposal of any extraction waste products.

\section{Module 2}

Material Processing encompasses the processing of the raw material, to get it ready to be used. This stage of the product life cycle includes the use of many different processes that are harmful to the environment, therefore it is a critical module in evaluating the total environmental impact.

\section{Module 3}

Manufacturing and Assembly evaluates the energy and resources used to manufacture the product, how much energy/material is lost during this stage as well as pollution produced from manufacturing and assembly of the final product.

\section{Module 4}

Product Use evaluates the actual use of the product for whatever purpose it has been created. Product use includes the effect on air, water and land pollution during use as well as efficiency of the product during use.

\section{Module 5}

Waste Management is one of the most critical phases of the product life cycle that is often overlooked. It has been included in the software not only to evaluate how this stage is handled but also to remind users of the importance of considering waste (residue) management in their design.

\section{Evaluating Results}

This software is mainly a qualitative analysis of the environmental impact of the product life cycle. Its measurement of environmental impact is not based mainly on the quantity of pollutants, energy, etc., but more so on what pollutants exist and what energy source is being used.

The environment rankings are from 0-10 with zero being no environmental impact and 10 being greatest detrimental effect to the environment. The corresponding rankings are based on how damaging each stage is known to be on a long-term scale.

\section{Sample Design Case Study: Generation of Electricity from either Coal or Solar Energy}

The software has been written two compare two specific cases, (a) use of coal to generate electricity and (b) use of solar energy to generate electricity. The database currently only includes data for these two processes. 


\section{Material Extraction}

What is the material to be extracted?

Use the pull down menu to select the raw material that is to be extracted from its natural state to be used to create electricity.

-Coal

-Quartz

What is the rate of extraction, units (tones per year)?

Select the rate the material is being extracted.

$-0-10$ million

$-10-20$ million

$-21-30$ million

$-31-40$ million

$-41-50$ million

$-51-60$ million

$-61-70$ million

$-71-80$ million

-> 80 million
Corresponding Rank

2

3

4

5

6

7

8

9

10

What type of energy is being used to power the extraction process?

Select the form of energy used to power the extraction process.

-Solar

-Fossil Fuel

-Hydroelectric power

-Fuel Cell

-Nuclear

-Wind
Corresponding Rank

1

9

5

3

10

1

What pollutants are released into the atmosphere as a result of the extraction?

The extraction process releases some form of air pollutants. Please select any known pollutants.

$-\mathrm{CO}_{2}$

$-\mathrm{CO}$

$-\mathrm{SO}_{\mathrm{x}}$

$-\mathrm{NO}_{\mathrm{x}}$

-Si Powder

-CFC-11

$-\mathrm{CH}_{4}$

$-\mathrm{N}_{2} \mathrm{O}$
Corresponding Rank

6
3
8
8
3
10
7
6

3

8

8

3

10

6

What pollutants are released into rivers, streams, groundwater, etc. as a result of extraction? Select any known water pollutants.

$-\mathrm{NO}_{\mathrm{x}}$

Corresponding Rank

$-\mathrm{SO}_{\mathrm{x}}$ 
Is any of the solid waste from the extraction stage placed in a landfill?

Does that extraction process produce any waste that is placed in a landfill for disposal?

Corresponding Rank

$\begin{array}{lll}\text {-Coal: } & \text { Yes } & 8 \\ & \text { No } & 0 \\ \text {-Quartz: } & \text { Yes } & 2 \\ & \text { No } & 0\end{array}$

\section{Rate the level of human risk involved in the extraction stage. $(0-10,10$ is highest)}

All processes involve some form of risk to human health or safety. In your opinion, please rank this risk.

\section{Corresponding Rank}

Input $\quad=$ ?

Total Environmental Rank for Material Extraction Module

$\sum($ corresponding rank $)=?$

\section{Material Processing}

What is the material being processed?

Use the pull down menu to select the material that is being processed to create electricity.

-Raw Coal

-Quartz

What process is being used?

Select the type of process.

-Quartz: $\quad$ Reduction and Purifying

-Coal: $\quad$ Washing and Purifying

\section{Corresponding Rank}

6

3

What is the efficiency of the process?

Select the efficiency of the process. For coal, this data is based on the quality of the coal. For quartz, this data is based on the average loss of quartz in the processing stage.

$\begin{array}{llr}\text {-Coal: } & 0-10 \% \text { ash } & 3 \\ & 11-25 \% \text { ash } & 5 \\ & 26-35 \% \text { ash } & 7 \\ & 36-50 \% \text { ash } & 9 \\ \text {-Quartz: } & 70-80 \% & 5 \\ & 81-90 \% & 4 \\ & 91-98 \% & 1\end{array}$

What type of energy is being used to power the process? 
Select the form of energy used to power the extraction process.

-Solar

Corresponding Rank

-Fossil Fuel

1

-Hydroelectric power

9

-Fuel Cell

5

-Nuclear

-Wind

How much energy is consumed during the processing?

Please select the amount of energy it takes to actually process the material.

Corresponding Rank

$\begin{array}{lll}\text {-Quartz: } & 100-120 \mathrm{Wh} / \mathrm{m}^{2} & 4 \\ & 121-140 \mathrm{Wh} / \mathrm{m}^{2} & 5 \\ & 141-160 \mathrm{Wh} / \mathrm{m}^{2} & 6\end{array}$

What pollutants are released into the atmosphere as a result of the processing?

The processing stage releases some form of air pollutants. Please select any known pollutants.

$-\mathrm{CO}_{2}$

$-\mathrm{CO}$

$-\mathrm{SO}_{\mathrm{x}}$

$-\mathrm{NO}_{\mathrm{x}}$

-Si Powder
Corresponding Rank

6

3

8

8

3

What pollutants are released into rivers, streams, groundwater, etc.?

Select any known water pollutants.

$-\mathrm{NO}_{\mathrm{x}}$

$-\mathrm{SO}_{\mathrm{x}}$

$-\mathrm{CaCl}_{2}$
Corresponding Rank

7

7

4

Is any of the solid waste from the processing stage placed in a landfill?

Does that processing the material produce any waste that is placed in a landfill for disposal?

$\begin{array}{ll}\text {-Coal: } & \text { Yes } \\ & \text { No } \\ \text {-Quartz: } & \text { Yes } \\ & \text { No }\end{array}$

\section{Corresponding Rank}

8

0

2

No

0

\section{Rate the level of human risk involved in the processing stage. (0-10, 10 is highest)}

All processes involve some form of risk to human health or safety. In your opinion, please rank this risk. 


\section{Corresponding Rank}

Input $\quad=$ ?

\section{Total Environmental Rank for Material Processing Module}

$\sum$ (corresponding rank) $=$ ?

Table 2. shows the comparative impact indices for generation of electricity for coal and solar energy. The relative importance is the sum of the impact for each variable index such as in the waste management life cycle stage. The relative importance of energy on the energy alternatives is 18. The absolute importance is a percentage, which represents the weight that the variable index has on to total impact. It is calculated by dividing the relative importance by the sum of impacts (PV and Coal). The twenty-year life span shows the dramatic difference between coal and solar over a twenty-year life span. The impact ratio within one year is 2.4 (Coal : PV) compared with 47.74 impact ratio for 20 year life span. This is due to the fact that the life expectancy of the solar cells is twenty years whereas coal has to be mined yearly in order to generate electricity.

The software written for this design is interactive with the user of the program. Figure 4 provides an introductory page to the program. Figure 5 a sample module design for material extraction input data and summation of total indices for a particular module.

\section{Future work}

There is much work to be done in making this software as useful as possible. So far the shell has been created in which to mold the entire design package. It is recommended that the database be extended to include data for several processes other than the existing case study. It is also necessary to include some form of quantitative analysis to give users a more specific value of the environmental impact. This will allow users to actually see what levels of pollution are being produced and if it cannot be avoided, at least, where reductions can be made. 
Table 2. Comparative Impact Indices for Generation of Electricity for Coal and Solar Energy.

\begin{tabular}{|c|c|c|c|c|c|c|c|c|c|c|c|c|c|}
\hline Life Cycle Stages & \multicolumn{6}{|c|}{ Material Extraction } & \multicolumn{7}{|c|}{ Material Processing } \\
\hline & \multirow[b]{2}{*}{ 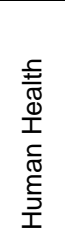 } & \multirow[b]{2}{*}{ 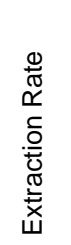 } & \multirow[b]{2}{*}{ 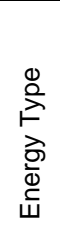 } & \multicolumn{3}{|c|}{ Emissions } & \multirow[b]{2}{*}{ 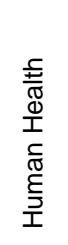 } & \multirow[b]{2}{*}{$\begin{array}{l}\mathbb{D} \\
\stackrel{2}{\beth} \\
\infty \\
\mathscr{D} \\
0 \\
0 \\
0\end{array}$} & \multirow[b]{2}{*}{ 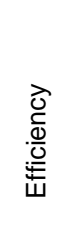 } & \multirow[b]{2}{*}{$\begin{array}{l}\text { के } \\
\text { Ф் } \\
\text { फे }\end{array}$} & \multicolumn{3}{|c|}{ Emissions } \\
\hline Energy Alternative & & & & 言 & $\frac{\bar{\Phi}}{\frac{ \pm}{3}}$ & 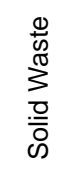 & & & & & $\dot{\bar{\alpha}}$ & $\frac{\Phi}{3}$ & 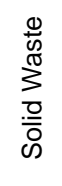 \\
\hline Solar Cells & 4 & 6 & 9 & 3 & 0 & 0 & 3 & 6 & 4 & 14 & 25 & 17 & 11 \\
\hline Coal & 7 & 4 & 9 & 17 & 0 & 0 & 4 & 3 & 7 & 9 & 9 & 3 & 14 \\
\hline RELATIVE IMPORTANCE & 11 & 10 & 18 & 20 & 0 & 0 & 7 & 9 & 11 & 23 & 34 & 20 & 25 \\
\hline ABSOLUTE IMPORTANCE & 1.63 & 1.48 & 2.67 & 2.97 & 0.00 & 0.00 & 1.04 & 1.34 & 1.63 & 3.41 & 5.04 & 2.97 & 3.71 \\
\hline
\end{tabular}

\begin{tabular}{|c|c|c|c|c|c|c|c|c|c|c|c|c|c|c|}
\hline Life Cycle Stages & \multicolumn{6}{|c|}{ Manufacturing \& Assembly } & \multicolumn{8}{|c|}{ Use } \\
\hline & \multirow[b]{2}{*}{ 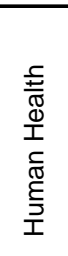 } & \multirow[b]{2}{*}{$\begin{array}{l}\text { के } \\
\frac{0}{\omega} \\
\text { 山े }\end{array}$} & \multirow[b]{2}{*}{ 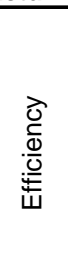 } & \multicolumn{3}{|c|}{ Emission } & \multirow[b]{2}{*}{ 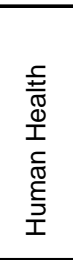 } & \multirow[b]{2}{*}{ 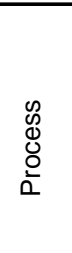 } & \multirow[b]{2}{*}{ 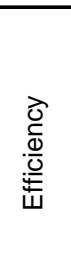 } & \multirow[b]{2}{*}{ 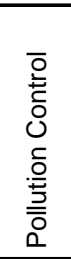 } & \multirow[b]{2}{*}{ 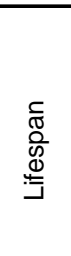 } & \multicolumn{3}{|c|}{ Emission } \\
\hline Energy Alternative & & & & 完 & $\frac{\frac{\Phi}{ \pm}}{\frac{\pi}{3}}$ & $\begin{array}{l}\frac{0}{10} \\
\stackrel{0}{3} \\
3 \\
\frac{0}{\overline{0}} \\
\text { c }\end{array}$ & & & & & & 言 & $\frac{\bar{\Phi}}{\frac{\pi}{3}}$ & $\begin{array}{l}\frac{0}{0} \\
\stackrel{\pi}{\pi} \\
3 \\
\frac{0}{\overline{0}} \\
\dot{\infty}\end{array}$ \\
\hline Solar Cells & 2 & 16 & 6 & 20 & 9 & 4 & 1 & 1 & 0 & 0 & 1 & 0 & 0 & 0 \\
\hline Coal & 0 & 0 & 0 & 0 & 0 & 0 & 5 & 8 & 2 & 3 & 10 & 195 & 144 & 8 \\
\hline RELATIVE IMPORTANCE & 2 & 16 & 6 & 20 & 9 & 4 & 6 & 9 & 2 & 3 & 11 & 195 & 144 & 8 \\
\hline ABSOLUTE IMPORTANCE & 0.30 & 2.37 & 0.89 & 2.97 & 1.34 & 0.59 & 0.89 & 1.34 & 0.30 & 0.45 & 1.63 & 28.93 & 21.36 & 1.19 \\
\hline
\end{tabular}




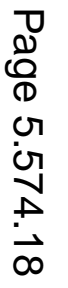


Table 2. Comparative Impact Indices for Generation of Electricity for Coal and Solar Energy (cont'd).

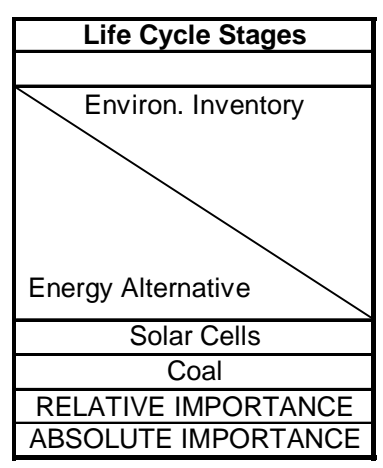

\begin{tabular}{|c|c|c|c|c|}
\hline \multicolumn{4}{|c|}{ Waste Management } & \\
\hline $\begin{array}{l}\text { के } \\
\frac{\bar{\omega}}{ \pm} \\
\text { फ }\end{array}$ & 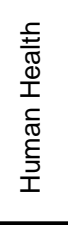 & 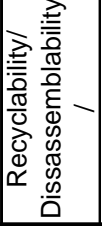 & 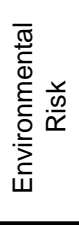 & 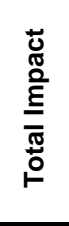 \\
\hline 9 & 0 & 28 & 0 & 199 \\
\hline 9 & 5 & 0 & 0 & 475 \\
\hline 18 & 5 & 28 & 0 & \\
\hline 2.67 & 0.74 & 4.15 & 0.00 & \\
\hline
\end{tabular}

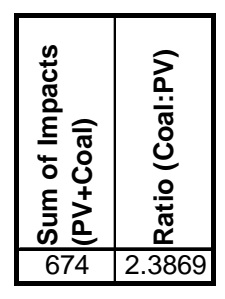

\begin{tabular}{|c|c|c|}
\hline 20 year life cycle impact & PV & Coal \\
\hline Year 1-5 & 199 & 2375 \\
\hline Year 6-10 & 0 & 2375 \\
\hline Year 11-15 & 0 & 2375 \\
\hline Year 16-20 & 0 & 2375 \\
\hline Total & 199 & 9500 \\
\hline
\end{tabular}

Based upon ratio

There is 2.4 times more impact from Coal that $P V$ for 1 year of use Over a 20 year life cycle the impact ratio is $\quad \mathbf{4 7 . 7 4}$ Coal to PV 


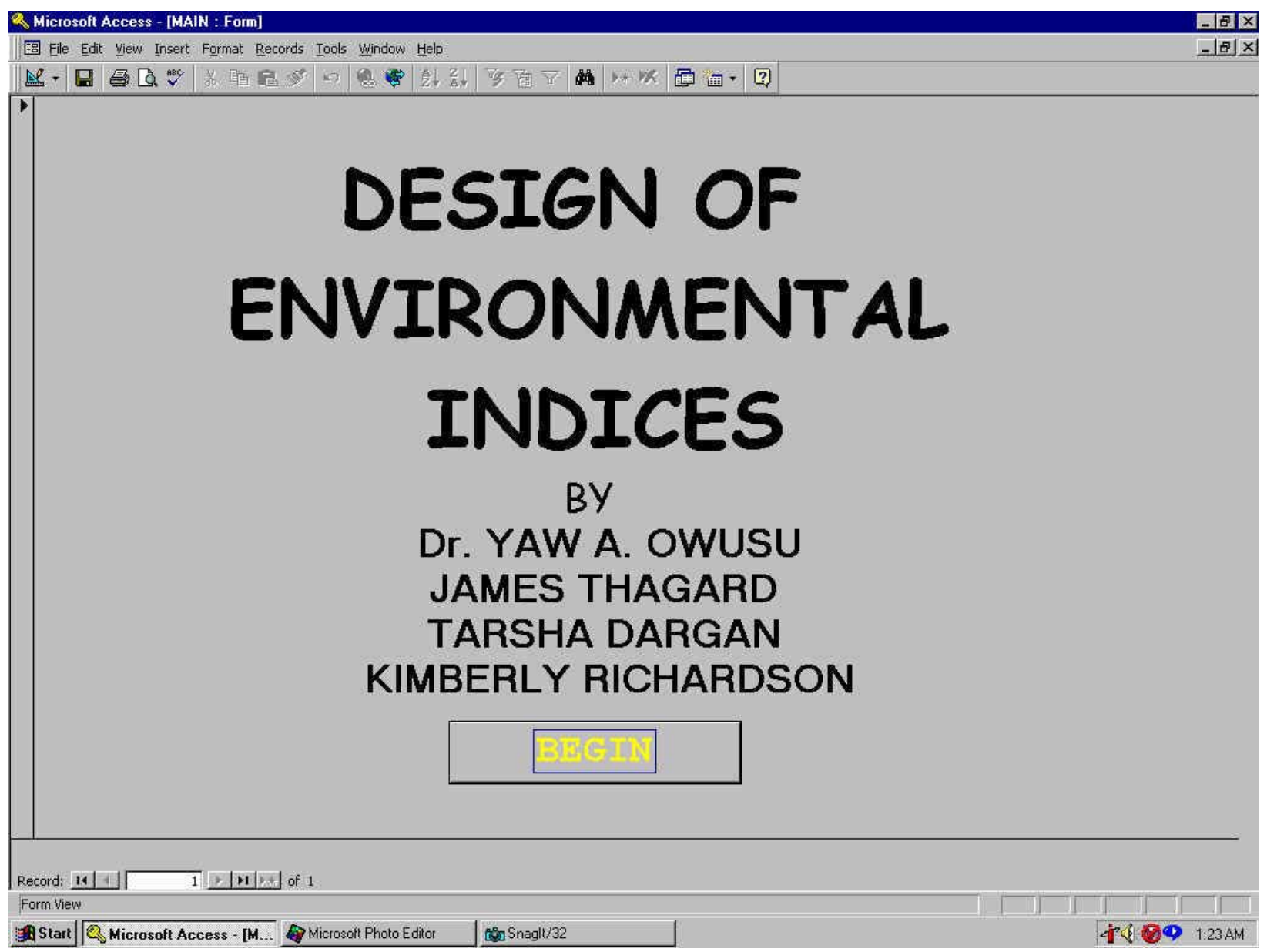

Figure 4. Introduction Page to Computer Program for ECDM Design. 


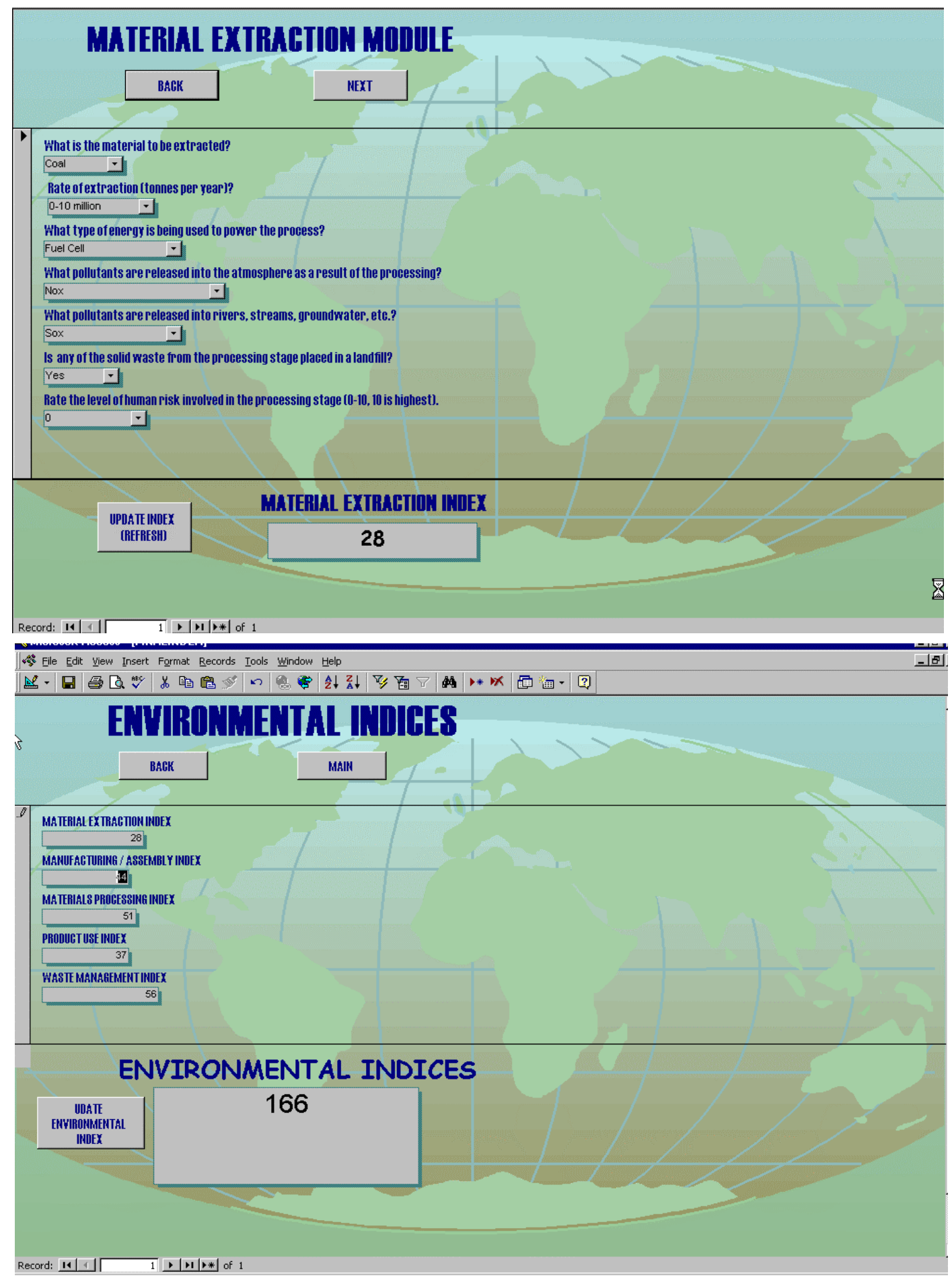

FIGURE 5 Sample Module Design for Material Extraction and Summation of Total Indices 


\section{Bibliography}

1. Boden, T. A., Kanciruk, P., and Ferrel, M.P., "Trends 1990, A Compendium of Data on Global Change, Report ORNL/CDIAC-36, p. 89, TN: Oak Ridge National Laboratory (1990).

2. Houghton, J.T., Jenkins, G.J., and Ephraums, J.J., "Climate Change: the PIPCC Scientific Assessment, Cambridge, UK: Cambridge University Press (1990).

3. Graedel, T.E. and Allenby, Industrial Ecology, AT \& T Laboratories, Prentice Hall, Englewood Cliff, New Jersey (1995).

\section{YAW A. OWUSU}

Yaw A. Owusu is an Associate Professor and Fulbright Fellow at Florida A \& M University-Florida State University College of Engineering in the Department of Industrial Engineering. Dr. Owusu is the Director of "Affordable Cutting-Edge Technology Center" at FAMU-FSU College of Engineering. Dr. Owusu has been appointed as an Associate Researcher at the Argonne National Laboratory since 1996, working on rapid prototyping technology for improvement on the manufacture of engines for airplanes. Dr. Owusu was awarded Senior Fulbright Fellow in 1997-1998 academic year to University of Science \& Technology in Kumasi, Ghana. He was a recipient of the A.D. Williver Boeing Professor of the Year Award in 1995. Dr. Owusu received a B.Sc. degree in Industrial Engineering from the University of Rhode Island in 1975 and a Ph.D. from Department of Industrial \& Systems Engineering from the Pennsylvania State University at University Park campus in 1980.

\section{TARSHA DARGAN}

Tarsha Dargan is currently a doctoral student at FAMU-FSU College of Engineering in the Department of Industrial Engineering, Florida A \& M University, Tallahassee, Florida. Her area of specialization is environmentally conscious design and manufacturing with emphasis on solar energy, smart materials, and smart sensors. Tarsha Dargan completed her BS/EE (Electrical Engineering) in 1996 and MS/IE in 1998 in Industrial Engineering from Florida A \& M University). Her MS thesis was on Statistical Analysis of Point Cloud Data from Coordinate Measuring Machine (CMM) and Application of Green Quality Function Deployment.

\section{KIMBERLY RICHARDSON}

Kimberly M. Richardson is an MS graduate student in the Department of Industrial Engineering at FAMU-FSU college of Engineering, Florida A \& M University, Tallahassee, Florida. She is a graduate of Tennessee State University with a B.Sc. degree in Mechanical Engineering. Her undergraduate research focused on a performance analysis of wind turbine blades under severe icing conditions and development alternative environmentally friendly deicing methods. Her major research areas of interest include manufacturing, simulation and production planning, and environmental issues. Her major career goals include returning to academia to teach and to encourage underprivileged youth to pursue careers in mathematics and science.

\section{JAMES THAGARD}

James Thagard is currently a doctoral student at FAMU-FSU College of Engineering in the Department of Industrial Engineering at Florida State University. He is a graduate of University of Houston with BS in Industrial Engineering. He also studied Human Factors and Ergonomics as a Masters student at the University of Houston. Currently James is working with composite materials as his Ph.D. research. James has worked in industry for NASA as a Quality Engineer, for Baker Oil Tools as a Manufacturing Engineer and with Boeing for Expendable Launch Vehicles. 